\title{
Narrando a Vida, Nossas Memórias e Aprendizados - Humanização no Ensino e na Assistência.
}

\author{
Mayer, Fernanda Brenneisen; Tempski, Patrícia; Padilha, Roberto de Queiroz; Oliveira, \\ Marilda Siriani de \\ Faculdade de Medicina da Universidade de São Paulo — fbmayer@usp.br
}

Introdução: a tradição de narrar vivências é uma herança cultural que forja a memória social. o processo de narrar a própria experiência possibilita a pessoa resignificar a sua trajetória e lhe oferecer novos sentidos, estabelecendo uma relação dialética, entre experiência e a reflexão. o uso de narrativas como estratégia para o desenvolvimento de uma visão crítica sobre a prática valoriza a dimensão subjetiva e social intrínsecas nos processos de educação e saúde. Objetivos: Analisar o sentido do humanizar atribuído por profissionais do Sistema Único de Saúde (SUS) a partir da narração de suas próprias histórias. Métodos: Durante um processo de formação de preceptores do SUS em dez cidades, foram coletadas 130 narrativas de vivências de humanização ou desumanização no ensino e na assistência. Essas narrativas foram submetidas a uma análise qualitativa com categorização, identificação de subcategorias e exemplificação por meio de trechos das narrativas. Resultados: Participaram do estudo 114 mulheres e 14 homens. a amostra foi heterogenia com relação à área de formação (enfermagem, fisioterapia, medicina, odontologia, psicologia e serviço social) e atuação (gestão, assistência e educação na saúde). Emergiram da análise qualitativa categorias analíticas que foram subdividias em valores e ações associadas à humanização na saúde. Os valores expressados como inerentes ao ato de humanizar foram: respeito à cultura do outro e suas singularidades, valoração do sujeito e da equipe de trabalho, amorosidade pelo outro e pela profissão, ética, profissionalismo, justiça e respeito aos direitos dos cidadãos e usuários do SUS. Entender os pressupostos da humanização do ensino e da assistência não significa agir com humanidade, pode tão simplesmente refletir o senso comum construído por nosso meio social. Neste sentido a humanização precisa ser expressa por mudanças de comportamento, exteriorizadas por ações que nas narrativas emergiram como: perceber a necessidade do outro, o contexto histórico e político do cuidado, reconhecer o outro como sujeito, acolher, demonstrar empatia, cuidar,, compreender e compartilhar. o ouvir, interagir e construir junto foram ações, ligadas ao núcleo de sentido do diálogo, ações que em conjunto buscam estabelecer relações horizontalizadas entre os membros da equipe de saúde, entre a equipe e o gestor, entre preceptor e estudante e entre profissional e paciente. a inclusão foi expressa como aceitação das diferenças de sexo, cor, etnia, escolaridade, de desenvolvimento e socioeconômicas. Conclusões: o desafio de pensar a humanização a partir das próprias vivências como profissional da saúde ou como aquele que adoeceu e necessitou de cuidado, fez com que emergissem das narrativas núcleos de sentido ligados aos valores e ações necessários à condição de humanizar. em síntese, eles reafirmam que o cuidar com excelência, resolutivo e digno, o compromisso radical com a autonomia dos sujeitos e a transformação de realidades representam a valorização do humano, ou humanização das práticas de ensino e cuidado.

Mayer, Fernanda Brenneisen; Tempski, Patrícia; Padilha, Roberto de Queiroz; Oliveira, Marilda Siriani de. Narrando a Vida, Nossas Memórias e Aprendizados - Humanização no Ensino e na Assistência.. In: Anais do Congresso Internacional de Humanidades \& Humanização em Saúde [= Blucher Medical Proceedings, num.2, vol.1]. São Paulo: Editora Blucher, 2014. ISSN 2357-7282

DOI 10.5151/medpro-cihhs-10604 